\title{
Analysis of Peeling Results of Red Meranti Wood Types on a Spindleless Rotary Lathe Machine at PT Rimba Raya Lestari, Kutai Kartanegara, East Kalimantan
}

\author{
Syafii $^{1,2 *}$ Edy Budiarso ${ }^{3}$ Bandi Supraptono ${ }^{3}$ Agus Sulistyo Budi ${ }^{3}$ \\ ${ }^{1}$ Post Graduate Program of Forestry Science, Forestry Faculty, Mulawarman University, Samarinda, East \\ Kalimantan, Indonesia \\ ${ }^{2}$ Samarinda State Agricultural Polytechnic, East Kalimantan, Indonesia \\ ${ }^{3}$ Forestry Faculty of Mulawarman University, Samarinda, East Kalimantan, Indonesia \\ *Corresponding author. Email: aliefsyafii.10@gmail.com
}

\begin{abstract}
Rotary lathe veneer peeling machines with large spindles are widely used in veneer and plywood factories in Indonesia. On average, half of the raw material logs become waste, and the rotary lathe contributes $25 \%$. Meanwhile, on the other hand, the world's need for plywood products will never disappear and even continue to increase. This is because plywood is one of the most environmentally friendly building material products and comes from renewable natural resources. With the regrowth of the plywood industry as in its former heyday, the consequence is that the demand for log raw materials will also increase, and the potential for loss of logs as waste will also increase. In this regard, there must be fundamental changes in this industry, including the shift in production machines from large rotary spindles to spindle-less. The purpose is to analyze its contribution to increasing the yield or peeled veneer volume. Furthermore, to find out the volume of the by-products, log-core, and waste spur-knife. The difference in results between the two variables, independent factors, were fed in rotary lathe machines without spindle (spindleless) was also tested. This study used a 3x5 factorial experimental design with two factors or fixed variables: quality class and the diameter range of log raw materials. Based on the analysis of the results of the calculations, this study shows that, in general, spindleless rotary lathe machines provide a yield of more than $60 \%$ of the raw material logs that are peeled off into a veneer, in the form of a continuous/endless veneer and a poly piece core/odd veneer, in all quality and diameter classes. The rest is waste in the form of round-up veneer and log-core up to $15 \%$ with an average diameter of $23 \mathrm{~cm}$. If stripping were continued to a diameter of $7 \mathrm{~cm}$, this would increase the finished yield more than $10 \%$. The statistical analysis showed that only the different rotary lathe types had a nearly significant effect on the peeled veneer's outcome. The interaction of the three factors tested also substantially affected the peeled veneer's yield.
\end{abstract}

Keywords: Spindleless rotary lathe, veneer, rendemen

\section{INTRODUCTION}

The need for veneer and/or plywood in the world will never disappear and will even continue to grow. This is because plywood is one of the most environmentally friendly construction materials and comes from sustainable natural resources. Therefore, it is vital to encourage the plywood industry to make positive changes, such as replacing raw materials from natural forest wood to tree wood, notably sengon wood.
It also needs to shift from large-scale to small and medium-scale industries and substitute large rotary spindles with rotary spindleless spindles. This one is significant because it offers a more substantial and better veneer yield. This study aims to provide an overview of the yield produced by the rotary spindleless peeling machine, mainly the product in the form of continuous veneer and veneer core of the poly piece, both of which are called green veneers. Even in the 
shape of a log-core, spurkine waste, and round-up veneer, to find out the number of by-products.

Wood that is widely used in Asia as raw material is mainly from the Dipterocarpaceae family [1]. Although this wood only occurs in mixed forests, more than half of the potential stand accounts for this type of dipterocarp. It is characterized only by strength, straightness, and knuckle-freeness such as Meranti Merah, Lauan Putih, and Mersawa. Other types are Jelutung and Ramin. For veneer manufacture, the condition that the logs must fulfill is that the fibers must be straight. Deviations from this rule are allowed to the degree that they are considered economical and meet the quality criteria since the logs used as veneer raw materials are expensive. And also, the logs must be circular or cylindrical, another specification. Dumanauw requires that it be wide in diameter, round, defect-free, or moderate weight to create a log veneer or plywood. Some examples are Meranti Merah, Meranti Putih, Nyatoh, Ramin, Agathis, and Benuang [2].

It also reported that the absence of knots or surface defects, straightness and cylindrical defects, and the free ends of defects decide the quality of round wood. For the veneer, the wooden defect is also a significant log problem. Typically, the quality class is defined based on straightness, free in the middle from rot or softness, and free from wood streaks or other defects. Also, for two reasons, the quality of logs entering the factory is essential: monitoring the quality of veneer produced and reducing the number of logs installed in a peeling machine prove to be defective. The pulping machine output speed can be decreased by faulty logs or sawn $\operatorname{logs}$ [3]. More detail the specifications for $\operatorname{logs}$ to be turned into sheets of veneer: available in large quantities, density between $0.35-0.8 \mathrm{~g} / \mathrm{cm}^{3}$, diameter > $40 \mathrm{~cm}$, straight and cylindrical stem, straight fibers, free of defects (such as knots, pinholes, broken ends, or surfaces), high mechanical properties, decorative texture, light color, and low price [4].

Kollmann et al. mentioned that rotary-peeling, which is the foundation of the modern plywood industry, produces most veneers. The purpose of rotarypeeling is to make endless veneers (long continuous finish), so they need to be rolled. Although not flawless, the veneer created in this way is smooth [1]. In Britannica, it is stated that more than $90 \%$ of the veneer is peeled. Still, the veneer made for furniture and other decorative uses from figurative wood is obtained by cutting. In contrast, the sawn veneer is rarely produced because it creates a lot of waste [5].

\section{MATERIAL AND METHODS}

\subsection{Materials}

The log of the Meranti Merah species is the material used in this study. The research was conducted at a manufacturing plant for plywood (ply mill), in Loa Kulu village, Kutai Kartanegara Regency, East Kalimantan, PT Rimba Raya Lestari (PT RRL).

\subsection{Veneer Peeling}

Logs that are typically 10-17 meters long were split into log-blocks of specific sizes: 3 ', 4', 6 ', and 8', and the results were calculated again to quantify the amount of raw material input in their length and diameter. Additionally, in the debarker log machine, the block was skinned to eliminate any skin and foreign or other items that stick to its surface. The block moved toward the log cleaning system from the log debarker, still with the same roll conveyor, to be sprayed with high-pressure water to clean the debris attached to the block. In this situation, no pretreatment was carried out, such as logblocking and boiling.

\subsection{Log Peeling}

The block was positioned on the conveyor chain deck to wait for the turn to decide the log-block centering, then moved to the rotary lathe. Until two spindles grasp the block, the hoist fitted with clamps performs this job. As the peeling process continues, the disk was pulled slowly so that only the knife-holder and the nozzle wheels clamped the block that remains spinning against the rodent blade. The long veneer (continuous veneer) was the outcome of this process. It was rolled up and then put on the reeling-unreeling veneer decks temporarily. Simultaneously, odd-veneer (poly piece core) and spur-knife waste were also produced beginning and at the end of the peeling process. The peeling process ended with the remains of a pith (log-core).

\subsection{Data Measurements}

The thickness of all peeled finishes, both face/back persistent finish, core finish (poly piece core), and spur knife waste, was measured. For the veneer coils on the reeling-unreeling veneer decks, the radius $(\mathrm{r}, \mathrm{cm})$ was also calculated to determine the diameter $(\mathrm{Bv}, \mathrm{m})$, as well as the length $(1 \mathrm{~cm})$. Then the veneer volume was measured after the diameter of the winding bobbin was known $(\mathrm{Bb}, \mathrm{m})$. The volume measured was marked as ( $\mathrm{V} \mathrm{cm} 3$ ). In order to determine the volume, the pith (log core) was calculated for both length (l) and diameter (d). 

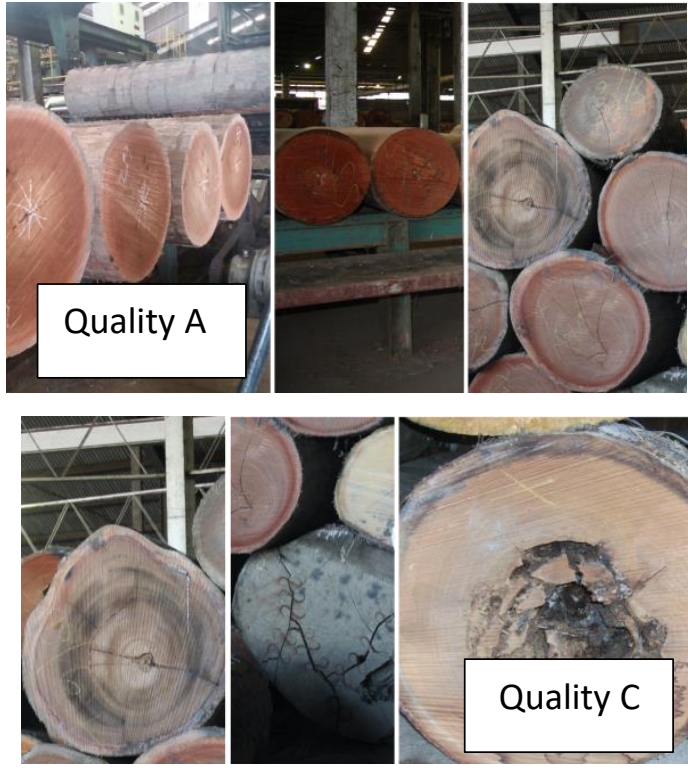
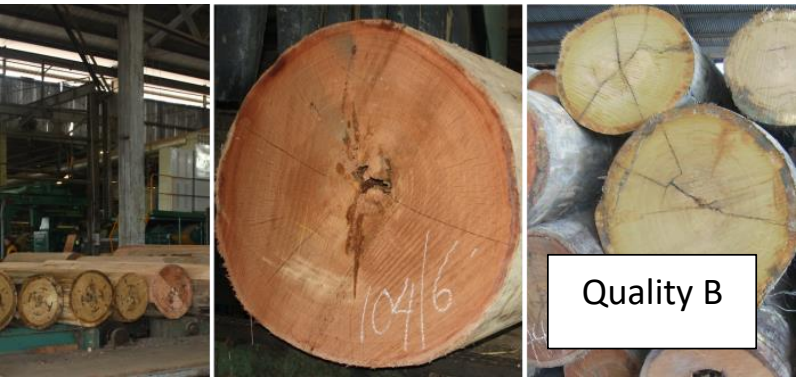

Quality A. The block is cylindrical, has no surface cracks, and free of defects such as the presence of hardwood eyes or weevils. Quality B. The block is quite cylindrical, no rotting wood-eyes, cracks in the cross-section, and the surface is justified as long as it can be overcome with or without the help of "S" plastic nails. Quality C. These blocks need special handling before peeling in a rotary machine. Because they are usually not cylindrical, bent, even the previous blocks were split in half due to severe open breaks, the presence of eye wood, and sapwood.

\subsection{Calculation}

Diameter measurement, log-block volume and volume of veneer rolls were measured using the formulas below [6]. Using equation 1, the log-block and pith diameter were determined.

$$
D=\frac{1 / 2\left[\left(d_{1}+d_{2}\right)+\left(d_{3}+d_{4}\right)\right]}{2}
$$

The volume of log-block and pith was calculated by equation 2 .

$$
V=\frac{1}{4} \pi D^{2} x l
$$

The gross volume of veneer in bobbin winding on reeling-unreeling machine was calculated by equation 3 .

$$
V=\frac{1}{4} \pi\left(B_{v}^{2}-B_{b}^{2}\right) x l
$$

Table 1. Average Percentage of the A Quality Log-block Peeling Result of the Red Meranti Type with Different Diameter Classes on the Spindleless Type Rotary Lathe Machine

The yield (rendement) of the veneer, both continuous veneer and poly piece core (PPC), was calculated using Equation 4 [7].

$$
\text { Yield }=\frac{\text { Veneer volume on each } \log }{\log \text { volume }} \times 100
$$

where:

\begin{tabular}{|c|c|c|c|c|c|c|c|c|}
\hline \multicolumn{4}{|c|}{ Log-block } & \multicolumn{5}{|c|}{ Rotary Machine Peeling Results (\%) } \\
\hline \multirow{2}{*}{$\begin{array}{c}\text { Diameter } \\
\text { Class }\end{array}$} & \multirow{2}{*}{$\begin{array}{l}\text { Average } \\
\text { Diameter } \\
\quad(\mathrm{cm})\end{array}$} & \multirow{2}{*}{$\begin{array}{c}\text { Average } \\
\text { Length }(\mathrm{cm})\end{array}$} & \multirow{2}{*}{$\begin{array}{c}\text { Average } \\
\text { Volume } \\
\left(\mathrm{m}^{3}\right)\end{array}$} & \multicolumn{2}{|c|}{ Green Veneer } & \multicolumn{3}{|c|}{ Waste } \\
\hline & & & & $\begin{array}{l}\text { Rolled } \\
\text { veneer }\end{array}$ & PPC & Pith & $\begin{array}{l}\text { Spur-knife } \\
\text { cuttings }\end{array}$ & Round-up \\
\hline 1 & 52.67 & 259.40 & 0.565 & 57.649 & 25.34 & 13.086 & 0.666 & 3.256 \\
\hline 2 & 56.33 & 259.90 & 0.648 & 62.599 & 23.20 & 9.924 & 0.827 & 3.449 \\
\hline 3 & 61.67 & 260.00 & 0.776 & 62.693 & 23.20 & 7.665 & 0.964 & 5.475 \\
\hline 4 & 67.00 & 259.53 & 0.915 & 61.377 & 22.23 & 7.627 & 0.894 & 7.876 \\
\hline 5 & 73.03 & 259.90 & 1.089 & 76.932 & 14.29 & 6.043 & 1.003 & 1.730 \\
\hline Average & 62.14 & 259.75 & 0.799 & 64.250 & 21.65 & 8.869 & 0.871 & 4.357 \\
\hline
\end{tabular}

D $\quad=\log$-block or pith diameter $(\mathrm{cm})$.

$\mathrm{d}_{1}, \mathrm{~d}_{2}, \mathrm{~d}_{3} \& \mathrm{~d}_{4}=$ the diameter of the 4 repetitions $(\mathrm{cm})$

$$
\begin{array}{ll}
\mathrm{V} & =\operatorname{volume}\left(\mathrm{m}^{3}\right) \\
\mathrm{L} & =\log \text { block or pith length }(\mathrm{m}) \\
\mathrm{Bv} & =\text { veneer rolls diameter }(\mathrm{m}) \\
\mathrm{Bb} & =\text { bobbin diameter }(\mathrm{m})
\end{array}
$$


Table 2. Average Percentage of the B Quality Log-block Peeling Result of the Red Meranti Type with Different Diameter Classes on the Spindleless Type Rotary Lathe Machine

\begin{tabular}{|c|c|c|c|c|c|c|c|c|}
\hline \multicolumn{4}{|c|}{ Log-block } & \multicolumn{5}{|c|}{ Rotary Machine Peeling Results (\%) } \\
\hline \multirow{2}{*}{$\begin{array}{c}\text { Diameter } \\
\text { Class }\end{array}$} & \multirow{2}{*}{$\begin{array}{c}\text { Average } \\
\text { Diameter } \\
\text { (cm) }\end{array}$} & \multirow{2}{*}{$\begin{array}{c}\text { Average } \\
\text { Length }(\mathrm{cm})\end{array}$} & \multirow{2}{*}{$\begin{array}{l}\text { Average } \\
\text { Volume } \\
\left(\mathrm{m}^{3}\right)\end{array}$} & \multicolumn{2}{|c|}{ Green Veneer } & \multicolumn{3}{|c|}{ Waste } \\
\hline & & & & $\begin{array}{l}\text { Rolled } \\
\text { veneer }\end{array}$ & PPC & Pith & $\begin{array}{l}\text { Spur-knife } \\
\text { cuttings }\end{array}$ & Round-up \\
\hline 1 & 49.97 & 261.47 & 0.515 & 59.135 & 20.24 & 14.24 & 0.653 & 5.741 \\
\hline 2 & 57.83 & 258.83 & 0.681 & 68.837 & 15.52 & 11.19 & 0.656 & 3.798 \\
\hline 3 & 62.57 & 259.60 & 0.798 & 60.828 & 24.86 & 9.75 & 0.662 & 3.896 \\
\hline 4 & 67.60 & 260.17 & 0.934 & 60.840 & 28.95 & 6.10 & 1.048 & 3.067 \\
\hline 5 & 77.67 & 261.50 & 1.240 & 62.516 & 24.50 & 6.23 & 0.906 & 5.847 \\
\hline Average & 63.127 & 260.31 & 0.834 & 62.431 & 22.81 & 9.501 & 0.785 & 4.470 \\
\hline
\end{tabular}

Table 3. Average Percentage of the C Quality Log-block Peeling Result of the Red Meranti Type with Different Diameter Classes on the Spindleless Type Rotary Lathe Machine

\begin{tabular}{|c|c|c|c|c|c|c|c|c|}
\hline \multicolumn{4}{|c|}{ Log-block } & \multicolumn{5}{|c|}{ Rotary Machine Peeling Results (\%) } \\
\hline \multirow{2}{*}{$\begin{array}{c}\text { Diameter } \\
\text { Class }\end{array}$} & \multirow{2}{*}{$\begin{array}{l}\text { Average } \\
\text { Diameter } \\
\text { (cm) }\end{array}$} & \multirow{2}{*}{$\begin{array}{c}\text { Average } \\
\text { Length }(\mathrm{cm})\end{array}$} & \multirow{2}{*}{$\begin{array}{c}\text { Average } \\
\text { Volume } \\
\left(\mathrm{m}^{3}\right)\end{array}$} & \multicolumn{2}{|c|}{ Green Veneer } & \multicolumn{3}{|c|}{ Waste } \\
\hline & & & & $\begin{array}{l}\text { Rolled } \\
\text { veneer }\end{array}$ & PPC & Pith & $\begin{array}{l}\text { Spur-knife } \\
\text { cuttings }\end{array}$ & Round-up \\
\hline 1 & 52.67 & 259.50 & 0.565 & 55.187 & 26.575 & 8.126 & 1.083 & 9.029 \\
\hline 2 & 56.56 & 259.77 & 0.654 & 54.341 & 20.226 & 10.307 & 0.129 & 14.996 \\
\hline 3 & 61.00 & 259.33 & 0.758 & 63.562 & 16.435 & 15.946 & 0.742 & 3.316 \\
\hline 4 & 71.00 & 259.43 & 1.027 & 53.005 & 19.976 & 11.746 & 0.905 & 14.369 \\
\hline 5 & 65.00 & 259.23 & 0.705 & 50.003 & 17.727 & 15.017 & 2.202 & 15.051 \\
\hline Average & 61.000 & 259.51 & 0.742 & 56.524 & 20.188 & 12.228 & 1.012 & 11.352 \\
\hline
\end{tabular}

\subsection{Treatment and experimental design}

The data and measurement results are then tabulated and evaluated based on a factorial experimental design with 2 treatments and each with 3 levels $x 5$ levels, to see the effect of treatment and interaction between treatments on the performance of peeled results in a rotary lathe machine, consisting of 1) Factor A (logblock quality) which consists of 3 levels, class A $\left(a_{1}\right)$, class $\mathrm{B}\left(\mathrm{a}_{2}\right)$ and class $\left.\mathrm{C}\left(\mathrm{a}_{3}\right) ; 2\right)$ and Factor $\mathrm{B}$ (diameter) which consists of 5 levels, diameter class $50-54 \mathrm{~cm}$ $\left(b_{1}\right), 55-59 \mathrm{~cm}\left(b_{2}\right), 60-64 \mathrm{~cm}\left(b_{3}\right), 65-69 \mathrm{~cm}\left(b_{4}\right)$, and $70-44 \mathrm{~cm}\left(\mathrm{~b}_{5}\right)$.

\section{RESULTS AND DISCUSSION}

The raw material observations include the log-block diameter, weight, and volume fed to the rotary lathe machine. The average diameter of the log-block fed to the spindleless rotary lathe is $63.13 \mathrm{~cm}$ (in quality class $\mathrm{A}$ ), $62.14 \mathrm{~cm}$ (quality B), and $61.00 \mathrm{~cm}$ (quality C), with almost the same average volume of $0.80 \mathrm{~m}^{3}$ in all three. The complete results of the log-block conversion to veneer in a rotary lathe spindleless machine are presented in Table 1, Table 2, and Table 3.

It was followed by 3 other forms of by-products like waste, i.e., waste spur knife, round-up veneer, and logcore, while peeling the log-block into a veneer sheet. The results showed that most of the peeling outcomes were $64.25 \%$ (for log-block A quality class), 62.43\% (B quality), and $56.524 \%$ (C quality), respectively, in the form of continuous/endless veneers. Next is the poly piece core veneer, $16,340 \%$ (quality A), $17.55 \%$ (quality B) and $20.19 \%$ (quality C), respectively, of PPC (odd veneer). In log-block quality classes $\mathrm{A}, \mathrm{B}$, and $\mathrm{C}$, the log-core volume is $8.87 \%, 9.50 \%$ and $12.23 \%$, respectively. The cut edges of the spur-knife cuttings that have been verified to be waste were $0.87 \%$ (logblock quality class A), $0.79 \%$ (quality B) and $1.012 \%$ (quality $\mathrm{C}$ ), while the number of the round-up was $4.36 \%$ (quality class log-block A), $4.47 \%$ (quality B), and $11.35 \%$ (quality $\mathrm{C}$ ). This result is better than other study which states that the result of peeling in a rotary 
lathe machine was $72.84 \%$ volume of logs, the remaining $27.16 \%$ was garbage. The veneer results ranged from $51.88 \%$ (for yellow meranti) to $74.55 \%$ for continuous veneer (for red meranti) [8]. The previous study also reported that $58 \%$ of the peeling results were endless veneers (full veneer), $27 \%$ odd veneers (nonintact finish for cores), $10 \%$ pith, and spur-knife waste with the round-up veneer of about 5\% [9].

The yield is also measured as the veneer-raw material ratio. This is referred to as green veneer recovery and offers an overview of the overall veneer yield that can be used [10], consisting of rolled veneer and PPC. The peeling outcome in the spindleless machine is $85.90 \%$ based on this assumption, composed of $64.25 \%$ rolled veneer and $21.15 \%$ PPC (see Table 1 ). On these two spindleless machines, the peeled yield value of quality class A blocks met the provisions of the 2009 Directorate General of Forestry Regulation concerning Processed Timber for Primary Industry Timber Forest Products (IPHHK), that the veneer yield of large diameter blocks peeled off by a rotary machine then logs is $77-81 \%$ of the remaining core shelled by rotary spindleless machine.

Research by McGavin found that the yield of fresh veneer ranged from $68-77 \%$ from several forms of Eucalyptus wood peeled on a rotary spindleless machine aged 10-16 years [11]. The yield of block A grade veneer is greater than the previous study, which stated that the rubberwood veneer yield peeled by a spindleless machine was in the 62-66\% range [7]. The commercial wood type veneer yield (large diameter logs) had averaged $71.0 \%$. This result was far below ours, which ranged from $78.42-85.90 \%$ [12]. The production of a veneer with 5 feet of spindleless rotary lathe from a palm trunk resulting in a yield in the range of 78.82$79.96 \%$ was also defined in Balfas and Malik's research [13]. A high proportion, $85.24 \%$, consisting of $62.43 \%$ rolled veneer and $22.81 \%$ PPC veneer, was still seen in the results of class B log-block peeling in the form of green veneer (Table 2). McGavin reported the yield of Eucalyptus globulus wood species aged 13-16 years with an average diameter of close to $50 \mathrm{~cm}$ in the form of green veneer, which is only 74-77\% [11]. The high yield of peeled veneer on this machine was caused by good quality inside the wood, which typically suggests healthy wood without rotting wood being present. In the block's cross-section in the direction of the radius, there were thin cracks noticed, but a plastic ' $S$ ' nail was still not needed to repair it. The peeling process went well, so the peeling worked optimally. And when the peeling process finished, there was no breakage.

On a rotary machine that can be measured as a veneer yield, the result of peeling quality $\mathrm{C}$ blocks is only around $76.71 \%$, consisting of $56.52 \%$ rolled finish and $20.19 \%$ PPC finish (Table 3). This outcome is lower than the peeling product of quality blocks A and B. The remaining $23.29 \%$ is from the first peeling in the form of waste, pith, remaining cut edges, round-up veneer, and irregularly formed veneer. The result of the rolled veneer reached $56.52 \%$ with a core finish of $20.19 \%$ with the following details. Pith, edge cut, and round-up were respectively $12.23 \%, 1.01 \%$, and $11.352 \%$. Nevertheless, the quantity of this yield also suggests that even though the consistency of the peeled log-block is the lowest, the spindleless machine can provide high peel yields.

Table 4. Analysis of Variety (ANOVA) Data of Continuous Veneer Volume in a 3 x 5 Factorial Experiment Design

\begin{tabular}{|c|c|c|c|c|c|c|c|}
\hline \multirow{2}{*}{ Diversity Sources } & \multirow{2}{*}{$\begin{array}{c}\text { Sum of Squares } \\
\text { (JK) }\end{array}$} & \multirow{2}{*}{$\mathrm{db}$} & \multirow{2}{*}{$\begin{array}{c}\text { Middle Square } \\
(\mathrm{KT})\end{array}$} & \multirow{2}{*}{ F-calculate } & \multicolumn{2}{|c|}{ F-table } & \multirow{2}{*}{ Sig. } \\
\hline & & & & & $5 \%$ & $1 \%$ & \\
\hline Treatment & $1792.298^{a}$ & 14 & 128.02 & $2.49^{*}$ & 2.06 & 2.8 & 0.018 \\
\hline Intercept & 165685.526 & 1 & 165685.53 & 3222.81 & & & 0.000 \\
\hline A factor $=$ Quality class & 662.710 & 2 & 331.355 & $6.45^{\star *}$ & 3.34 & 5.45 & 0.005 \\
\hline B factor $=$ Diameter & 349.891 & 4 & 87.47 & $1.70^{\text {ns }}$ & 2.71 & 4.07 & 0.176 \\
\hline$A^{*} B$ factor interaction & 779.697 & 8 & 97.46 & $1.9^{n s}$ & 2.29 & 3.23 & 0.098 \\
\hline Error & 1542.307 & 30 & 51.41 & & & & \\
\hline Total & 169020.13 & 45 & & & & & \\
\hline Corrected Total & 3334.605 & 44 & & & & & \\
\hline
\end{tabular}

a. $\mathrm{R}$ Squared $=.537$ (Adjusted R Squared $=.322$ )

Notes:

$\mathrm{ns}=$ no different on $\alpha=0,05$

$* *=$ very different on $\alpha=0,01$

If the value of $\mathrm{F}_{\text {-calculate }}>\mathrm{F}_{\text {-table }}$, then the treatment has a significant influence $* *$ )

If the value of $\mathrm{F}_{\text {-calculated }}<\mathrm{F}$-table, the treatment does not have a significant effect (ns) 
Table 5. Analysis of Variety (ANOVA) Data of Poly Piece core Volume in a 3 x 5 Factorial Experiment Design

\begin{tabular}{|c|c|c|c|c|c|c|c|}
\hline \multirow{2}{*}{ Diversity Sources } & \multirow{2}{*}{$\begin{array}{c}\text { Sum of Squares } \\
\text { (JK) }\end{array}$} & \multirow{2}{*}{$\mathrm{db}$} & \multirow{2}{*}{$\begin{array}{c}\text { Middle Square } \\
\qquad(\mathrm{KT})\end{array}$} & \multirow{2}{*}{ F-calculate - } & \multicolumn{2}{|c|}{ F-table } & \multirow{2}{*}{ Sig. } \\
\hline & & & & & $5 \%$ & $1 \%$ & \\
\hline Treatment & $972.011^{a}$ & 14 & 69.429 & $4.965^{\star *}$ & 2.06 & 2.8 & 0.000 \\
\hline Intercept & 15365.381 & 1 & 15365.381 & 1098.74 & & & 0.000 \\
\hline A factor = Quality class & 35.476 & 2 & 17.738 & $1.27^{\mathrm{ns}}$ & 3.34 & 5.45 & 0.296 \\
\hline B factor $=$ Diameter & 277.898 & 4 & 69.474 & $4.97^{* *}$ & 2.71 & 4.07 & 0.003 \\
\hline$A^{*} B$ factor interaction & 658.637 & 8 & 82.330 & $5.89^{* *}$ & 2.29 & 3.23 & 0.000 \\
\hline Error & 419.538 & 30 & 13.985 & & & & \\
\hline Total & 16756.930 & 45 & & & & & \\
\hline Corrected Total & 1391.549 & 44 & & & & & \\
\hline
\end{tabular}

a. R Squared $=.699$ (Adjusted R Squared $=.558$ )

Notes:

ns $=$ no different on $\alpha=0,05$

$* *=$ very different on $\alpha=0,01$

If the value of $\mathrm{F}_{\text {-calculate }}>\mathrm{F}_{\text {-table }}$, then the treatment has a significant influence $* *$ )

If the value of $\mathrm{F}_{\text {-calculated }}<\mathrm{F}$-table, the treatment does not have a significant effect (ns)

An additional 1\% low-quality veneer, sawn-log peeling on traditional rotary machines, resulted in $43 \%$ full veneer in theory. Losses were attributed to $6 \%$ rounding, $3 \%$ shrinkage, and $2 \%$ veneer tearing [3]. The loss of end and edge cutting (log end) was $26 \%$ and $19 \%$ of pith. The number of green veneers varies from $45.89 \%$ to $55.05 \%$ [14]. Therefore, the spindleless rotary lathe has a great potential to replace the old rotary lathe model that typically has a large spindle or disc diameter, which adds to the waste of block peeling to a veneer. So, replacing the traditional rotary type with the spindleless type is a wise move to restore the veneer and plywood industry's glory and development as in the past two decades. Plywood is the primary product of woodbased materials, specifically panel products in woodderived from forest products.

\subsection{Rolled Veneer (Continuous Veneer)}

The ANOVA table below (Table 4) based on several references [15-17], shows that the percentage of rolled veneer volume produced on block peeling is affected by the block quality class treatment. At the test stage, both $\alpha=0.01$ and $\alpha=0.05$, indicated by the F-table value higher than the F-count value. But this is not the case with the diameter class, which does not affect the peeled veneer percentage. This study shows that there is a substantial impact on the yield of the rolled veneer in the block consistency class. As with the diameter class and the treatment interactions, it turned out that the volume of the generated rolled veneer was not affected. Even the F-count value was much smaller than the Ftable at $\alpha=0.05$.

This spindleless rotary lathe machine can produce a pith with a minimum diameter of $7 \mathrm{~cm}$. In these calculations, if the peeling is continued until the core reaches the minimum diameter as indicated, an additional yield of $5-10 \%$ or even higher will be obtained if sawn logs with a diameter of 8 inches $(16.25$ $\mathrm{cm})$ were peeled to a pith diameter of 4 inches $(10 \mathrm{~cm})$. It would give a very significant yield of about $21 \%$ [18].

\subsection{Poly Piece Core}

The analysis of the diversity of the core veneer data, the poly piece core, illustrates conditions that are not so different. The block quality class treatment's F-count value indicates a value greater than the F-table value, at level $\alpha=0.05$, but not greater than F-table $\alpha=0.01$ (Table 5). So, it can be seen that the quality of blocks has a considerable influence on yield. The core veneer peeled at a test level of 5\%. However, this is not the case with the diameter class, which does not have a significant impact on the production of veneer cores of poly pieces.

The raw material blocks fed to the peeling machine are usually relatively cylindrical since they have been sorted in such a way from the beginning, except in certain situations, such as a shortage of raw material logs. However, when peeling, the log-block that is not cylindrical is a significant contributor to the poly piece core acquisition. In this case, the treatment interaction also did not significantly affect the volume of the peeled yield, both at $\alpha=0.05$ and $\alpha=0.01$. This ensures that the treatment does not interfere between the quality class and the two's diameter so that it does not affect the volume of the manufactured veneer core.

\subsection{Pith (Log-core)}

The ANOVA in Table 5 indicates that at the alpha $=$ 0.05 or alpha $=0.01$, all F-count values of the applied factors represent higher values than the F-table. The treatments, therefore, have a significant effect on the pith percentage (log-block core). The amount of leftover pith peeled is usually suppressed by good block quality 
and wide diameter, which increases the volume of the peeled veneer. The diameter of the core has a direct effect on the number of finishes produced [18]. The resulting increase in veneer in 18 inches $( \pm 50 \mathrm{~cm})$ sawn $\log$ s was by reducing the pith diameter from 5 to 4 inches (from $12.5 \mathrm{~cm}$ to $10 \mathrm{~cm}$ ), but the increase was not significant (only about 3\%). But the difference becomes vast if the 8 inches $(16.25 \mathrm{~cm})$ of sawn logs are peeled (about $21 \%$ ).

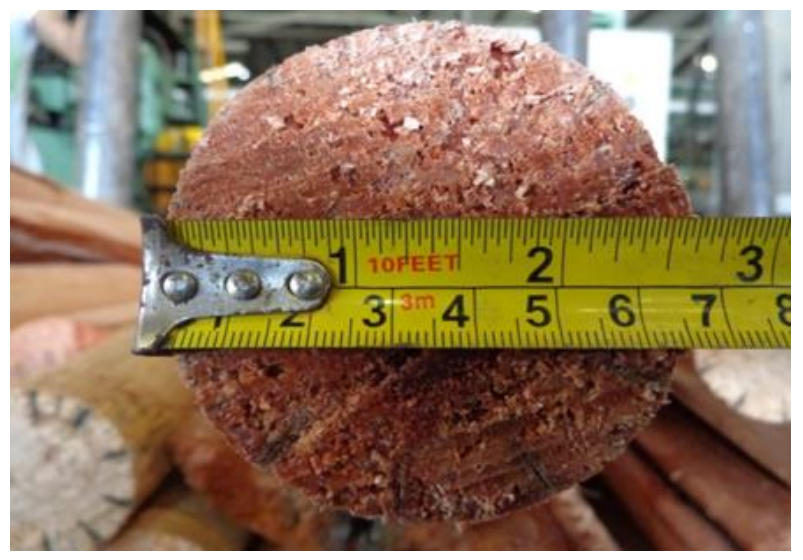

Figure 2 Minimum diameter pith on a spindleless rotary lathe machine (Photo taken by the researcher at PT Rimba Raya Lestari, Kutai Kertanegara, Kaltim)

Theoretically, the pith volume's size indicated by the diameter size would be affected by the raw material $\log$ block's nature, especially if the $\log$ is healthy, sufficiently cylindrical, and free of cracks. But with a note that, for some purposes, rotary machine operators do not interrupt the peeling operation.

\subsection{Spur-Knife waste}

The block quality factor, indicated by the F-count value that exceeds the F-table value at the $5 \%$ and $1 \%$ test levels and the diameter class, significantly impacts the edge cut waste veneer. The interaction of the two treatments also has a very substantial impact. Logically, since the cut edge veneer's width on both sides of the rotary engine cutter is more determined by the original block's length, the actual percentage of cut edge veneer is not directly related to the consistency of the original block. The cut edge veneer will be small if the block length is similar to the targeted measurement. On the other hand, if an overall excess size (allowance) is given to the block cutting, it will inevitably provide a big remaining edge cut. The edge cutout volume will increase or become high in this case.

Table 6 shows that all types of treatment significantly affect the percentage of cut edges, based on the study of variance (ANOVA) on the variance sources in this experiment. The volume of cut edges is more affected by the excess of the log-block length, which is often too wide, far exceeding the veneer length targeted.

\subsection{Round-up Waste Veneer}

This type is a type that can no longer be used in the veneer and plywood making process. This is due to the veneer's unusual size, not intact, and having transverse fibers. Usually, this waste is used for a steam boiler machine that supplies the plant, and the excess was burned. This waste is very high, with $4.36 \%$ of Class A quality logblock peeling, $4.47 \%$ of Quality B, and $11.35 \%$ of Quality $\mathrm{C}$. The rounding process is the most significant contributor to this waste at the beginning of the peeling, mainly when

Table 6. Analysis of Variety (ANOVA) Data of Log Core Volume in a 3x5 Factorial Experiment Design

\begin{tabular}{|c|c|c|c|c|c|c|c|}
\hline \multirow{2}{*}{ Diversity Sources } & \multirow{2}{*}{$\begin{array}{c}\text { Sum of Squares } \\
\text { (JK) }\end{array}$} & \multirow{2}{*}{$\mathrm{db}$} & \multirow{2}{*}{$\begin{array}{l}\text { Middle Square } \\
\qquad(\mathrm{KT})\end{array}$} & \multirow{2}{*}{ F-calculate- } & \multicolumn{2}{|c|}{ F-table } & \multirow{2}{*}{ Sig. } \\
\hline & & & & & $5 \%$ & $1 \%$ & \\
\hline Treatment & $441.675^{\mathrm{a}}$ & 14 & 31.548 & $7.096^{* *}$ & 2.06 & 2.8 & 0.000 \\
\hline Intercept & 3733.734 & 1 & 3733.734 & 839.77 & & & 0.000 \\
\hline A factor $=$ Quality class & 3.500 & 2 & 1.750 & $0.39 n s$ & 3.34 & 5.45 & 0.678 \\
\hline B factor = Diameter & 85.149 & 4 & 21.287 & $4.79^{* *}$ & 2.71 & 4.07 & 0.004 \\
\hline$A^{*} B$ factor interaction & 353.026 & 8 & 44.128 & $9.93^{* *}$ & 2.29 & 3.23 & 0.000 \\
\hline Error & 133.384 & 30 & 4.446 & & & & \\
\hline Total & 4308.793 & 45 & & & & & \\
\hline Corrected Total & 575.059 & 44 & & & & & \\
\hline
\end{tabular}

a. R Squared $=.768$ (Adjusted R Squared $=.660$ )

Notes:

ns $=$ no different on $\alpha=0,05$

$* *=$ very different on $\alpha=0,01$

If the value of $\mathrm{F}_{\text {-calculate }}>\mathrm{F}_{\text {-table }}$, then the treatment has a significant influence $* *$ )

If the value of $\mathrm{F}_{\text {-calculated }}<\mathrm{F}$-table, the treatment does not have a significant effect (ns) 
the block conditions are not cylindrical, sapwood, and surface cracks are present. That is why, relative to grade A and grade $\mathrm{B}$ veneer waste, grade $\mathrm{C}$ blocks have the most considerable veneer waste quantity, which is almost three times the size. The variance analysis indicates that the treatment factors applied significantly affect the percentage or volume of waste. There is a significant influence on the rate of waste in the relationship between the two treatments. Thus, the volume and the percentage of veneer peeling waste can be minimized by a good block quality followed by a proportional diameter.

\section{CONCLUSION}

The average peeled sawn-log (log-block) yield in the form of a rolled veneer (continuous/endless veneer) on a rotary lathe spindleless machine is $56,52 \%$ to $64.25 \%$ and $16,34 \%$ to $20.19 \%$ in the form of PPC (poly piece core). The log-core volume, meanwhile, ranged from $8.87 \%$ to $12.23 \%$. On average, the spur-knife waste veneer is between $0.79 \%$ and $1.012 \%$.

It turns out that the block quality, based on statistical tests with a factorial experimental design, has, in general, a very significant impact on both the rolled and the core veneers. Meanwhile, the peeled veneer percentage, both rolled and core veneer, was not affected by the diameter class. There was also no significant effect on veneer yield and other peel results from the interaction between the two treatments studied.

\section{ACKNOWLEDGMENT}

Authors states that no conflict of interest occur. Author also thankful for all the help throughout the research process.

\section{REFERENCES}

[1] F.F.P. Kollmann, W.A.J. Cote, Principles of Wood Science and Technology, Germany: Springer-Verlag Berlin and Heidelberg GmbH \& Co. KG, 2012.

[2] J.F. Dumanauw, Mengenal Kayu, Kanisius, Yogyakarta, 2003.

[3] J.L. Bowyer, R. Shmulsky, J.G. Haygreen, Forest Products and Wood Science: An Introduction 5th Edition, Wiley-Blackwell, 2007.

[4] D. H. Almeida, F.S. Ferro, L.D. Varanda, A.M. de Souza, F.H. Icimoto, A.L. Christoforo, F.A.R. Lahr, Quality control in plywood manufacturing: physical properties of commercial plywood of Pinus sp., International Journal of Composite Materials, 2013, pp. 163-167.

[4] T. Britannica, "Veneer", Encyclopedia Britannica, 2019, Available from: https://www.britannica.com/topic/veneer.
[5] Syafii, Kayulapis, Teknik Pembuatan, Sifat-Sifat \& Kegunaannya, Garis Putih Pratama, Makassar, 2019.

[6] P.S. Khoo, H.P. San, K.L. Chin, E.S. Bakar, M.L. Mamiski, R. Raja-Ahmad, C.L. Lee, S.N. Ashikin, M.H. Saharudin, Peeling of small diameter rubber log using spindleless lathe technology: evaluation of veneer properties from outer to inner radial section of $\log$ at different veneer thicknesses, European Journal of Wood and Wood Products 76(3), 2018. DOI: 10.1007/s00107-018-1300-5

[7] A. Schulte, D. Schöne, Dipterocarp Forest Ecosystems: Towards Sustainable Management, World Scientific Publishing, Singapore, 1996.

[8] Syafii, Analisis Volumetrik Konversi Kayu Bulat Menjadi Lembaran Finir pada Industri Kayulapis, Buletin Poltanesa, Samarinda, Vol 1, Nomor 1, 2001.

[9] R.L. McGavin, H. Baillères, M. Hamilton, D. Blackburn, M. Vega, B. Ozarska, Variation in Rotary Veneer Recovery from Australian Plantation Eucalyptus globulus and Eucalyptus niten, BioResources, 10, 2014.

[10] R.L. McGavin, H. Baillères, F. Lane, D. Blackburn, M. Vega, B. Ozarska, Veneer Recovery Analysis of Plantation Eucalypt Species Using Spindleless Lathe Technology, Bioresources, 9, 2014, pp. 613-627.

[11] Alfian, Lusyiani, N.M. Sari, Rendemen Finir pada Mesin Rotary Berdasarkan Kelompok Jenis Kayu pada Industri Kayulapis di PT Surya Satrya Timur. Sylva Scienteae, 2(4), 2019.

[12] J. Balfas, J. Malik, Pengaruh Umur Pohon, Posisi Batang, Tebal Venir dan Komposisi Panel Inti Sawit Terhadap Produksi Kayu Lapis Mindi, Jurnal Penelitian Hasil Hutan, 38(3), 2020. Pp. 189-198.

[13] R.F. Baldwin, Plywood and Veneer-based Products: Manufacturing Practices 3rd Edition, Miller Freeman Books, San Fransisco, 1995.

[14] V. Gaspersz, Metode Perancangan Percobaan: Untuk Ilmu-Ilmu Pertanian, Ilmu-Ilmu Teknik, dan Biologi, Armico, Bandung, 1991.

[15] K.A. Gomez, A.A. Gomez, K.A. Gomez, Statistical procedures for agricultural research, Wiley, New York, 2011.

[16] R.G.D. Steel, J.H. Torrie, D.A. Dickey, Principles and procedures of statistics: a biometrical approach, McGraw-Hill, New York, 1997.

[18]D.R. Philips, J.G. Schroeder, A. Clark, Reduce Pine Veneer Losses by Selecting Blocks Properly. Forest Industry, 107(4), 1980. 